Dikirim: 20 Juni 2016 Diterbitkan: 1 April 2017

\title{
Kualitas relasi orang tua-anak dan resiliensi pada orang tua dengan anak disabilitas intelektual
}

The quality of parent-children relationship and resilience among parents with children with intellectual disability

Amalia Senja ${ }^{1}$, Soewadi Soewadi ${ }^{2}$, Intansari Nurjannah ${ }^{3}$

\begin{abstract}
Purpose: This study was conducted to know the relation between quality of parent-child relationship and resilience among parents of children with intellectual disability. Methods: This cross-sectional study was conducted from June - July 2015 at SLB N 1 Bantul Yogyakarta city while the instrument test was conducted on 20 parents who had children with intellectual disability in SLB Darma Bhakti Piyungan, Yogyakarta. The population in this study were all parents with children with intellectual disability in SLB N 1 Bantul from TKLB level to SMALB. The samples were 60 respondents. Results: This study found no association between the quality of parent-child relationships with parental resilience with intellectual disability children. Conclusion: The authors suggest that resilience variables are not directly linked to the variable quality of relations but there are also other variables that influence it such as social support and others.
\end{abstract}

Keywords: quality of relations; resilience; intellectual disabled

\footnotetext{
${ }^{1}$ Stikes Kusuma Husada Surakarta (Email: amaliasenjaugm@gmail.com)

${ }^{2}$ Departemen Ilmu Kedokteran Jiwa, Fakultas Kedokteran Universitas Gadjah Mada

${ }^{3}$ Departemen Keperawatan Dasar dan Emergensi, Fakultas Kedokteran, Universitas Gadjah Mada
} 


\section{PENDAHULUAN}

Anak dengan ketidakmampuan belajar secara umum merasa memahami pelajaran dibandingkan anak lain pada usia sama. Anak dengan ketidakmampuan belajar dapat terus mempelajari hal baru dan membuat kemajuan sepanjang hidup, tetapi kecepatan belajar lebih lambat dibandingkan anakanak lain. Pedoman Penggolongan Diagnosis Gangguan Jiwa (PPDGJ) III menggolongkan ketidakmampuan belajar tersebut dengan anak disabilitas intelektual. Maslim mendefinisikan disabilitas intelektual sebagai "suatu keadaan perkembangan jiwa yang terhenti atau tidak lengkap, yang terutama ditandai oleh terjadinya kendala keterampilan selama masa perkembangan, sehingga berpengaruh pada tingkat kecerdasan secara menyeluruh, misalnya kemampuan kognitif, bahasa, motorik, dan sosial.” (1)

Berdasarkan data dari Dinas Sosial Provinsi DIY tahun 2006, jumlah anak anak disabilitas intelektual di Yogyakarta adalah sebanyak 1256 anak, sedangkan pada tahun 2013 meningkat menjadi 1322 dengan insidensi terbanyak di Kabupaten Sleman 353 (26,7\%), Gunung Kidul 306 (23,1\%), Bantul 260 (19,7\%), Kulon Progo 273 (20,7\%), dan Kota Yogyakarta 130 (9,8\%).

Orang tua yang memiliki anak dengan disabilitas intelektual mengalami berbagai tantangan berbeda dibandingkan dengan orang tua yang memiliki anak normal. Berbagai sumber stres yang mereka alami berbeda dengan orang tua umum (2). Pengasuhan orang tua yang optimal pada anak disabilitas intelektual dapat dicapai apabila orang tua mampu menghadapi tekanan, dan masalah, serta menjadi individu kuat dan optimis. Hal tersebut merupakan karakteristik individu yang memiliki resiliensi atau ketahanan.

Suatu hal mustahil bagi seorang ibu yang memiliki anak disabilitas intelektual untuk menjadi tangguh tanpa proses yang melibatkan faktor-faktor pendukung baik yang datang dari dalam individu tersebut maupun dari lingkungan (3). Salah satu faktor protektif atau faktor pendukung yang dapat mengubah, mengurangi atau meningkatkan respon individu terhadap pengaruh lingkungan yang memberi kecenderungan untuk mengalami perkembangan maladaptif adalah keluarga yang stabil dan memberikan dukungan yang ditandai pertalian diantara anggota keluarga (3).

Sekolah luar biasa (SLB) Negeri 1 Bantul mendidik sebanyak 148 anak disabilitas intelektual. SLB ini memiliki layanan medik klinik rehabilitasi dan tumbuh kembang anak berkebutuhan khusus (ABK) dan unit kesehatan sekolah (UKS), termasuk biro konsultasi dan psikologi. Menurut salah seorang psikolog biro konsul- tasi dan psikologi di UKS SLBN 1 Bantul, beberapa orang tua yang pernah berkonsultasi menolak dan menyalahkan saat mengetahui bahwa anak menderita disabilitas intelektual. Orang tua pesimis terhadap masa depan anak. Reaksi orang tua berbeda ketika sudah lama menyekolahkan anaknya di SLB karena secara umum orang tua telah bertemu dengan komunitas sama. Banyak dari orang tua yang memiliki kekeliruan dalam pengasuhan. Mereka cenderung permisif dan memanjakan anak, sehingga anak kurang dapat dikendalikan dan kurang mandiri. Perlu penelitian yang berkontribusi terhadap urgensi kualitas relasi orang tua pada anak disabilitas, sehingga penelitian ini bertujuan menganalisis hubungan kualitas relasi orang tua-anak dengan resiliensi orangtua anak disabilitas intelektual.

\section{METODE}

Penelitian menggunakan pendekatan kuantitatif dan dalam waktu yang bersamaan dilakukan wawancara mendalam untuk memberikan gambaran kualitas relasi dan resiliensi orang tua anak disabilitas intelektual. Penelitian cross sectional ini dilakukan bulan Juni -Juli 2015 di SLB N 1 Bantul kota Yogyakarta, sedangkan uji coba instrumen dilakukan pada 20 orang tua di SLB Darma Bhakti Piyungan, Yogyakarta. Populasi adalah semua orang tua dengan anak disabilitas intelektual di SLB N 1 Bantul dari tingkat TKLB sampai SMALB.

Survei dari hasil studi pendahuluan menunjukkan bahwa jumlah populasi adalah sebanyak 148 keluarga. Sampel diambil secara stratified sampling dan didapatkan 60 responden kuantitatif dan 3 responden kualitatif. Pengambilan sampel ini berasal dari kriteria inklusi, meliputi orang tua yang berpengalaman langsung merawat anak disabilitas intelektual ringan dan sedang, orang tua anak disabilitas intelektual yang bersekolah di SLB N 1 Bantul, orang tua telah menikah dan tinggal bersama menjadi pengasuh utama anak sehari-hari, orang tua yang bersedia menjadi responden. Kriteria eksklusi adalah orang tua yang sakit.

Variabel bebas adalah kualitas relasi. Variabel terikat adalah resiliensi keluarga. Instrumen kualitas relasi orangtua-anak menggunakan Parent-Child Relationship Questionnaire (PCRQ), dan telah dilakukan uji validitas dan reliabilitas menghasilkan 29 item valid dengan $r>0,3783$ ( $r$ tabel). Berdasarkan uji reliabilitas yang dilakukan, nilai Uji Statistik Cronbach Alpha adalah sebesar 0,928. Kuesioner resiliensi diukur melalui tujuh aspek resiliensi yang dapat dilihat dalam diri individu meliputi pengaturan emosi, kontrol 
terhadap impuls, empati, optimisme, analisis kausal, efikasi diri, dan pencapaian dalam skala likert. Hasil uji validitas menghasilkan 35 item valid dan hasil reliabilitas 0,914 yang dinilai reliabel (3).

\section{HASIL}

Tabel 1 menunjukkan mayoritas responden berjenis kelamin laki-laki, usia anak 5-11 tahun, mampu membaca dan menulis.

Tabel 1. Distribusi karakteristik orang tua dengan anak disabilitas intelektual

\begin{tabular}{lc}
\hline Karakteristik & \% (n=60) \\
\hline Jenis Kelamin & 70 \\
Laki - laki & 30 \\
Perempuan & 100 \\
Total & \\
Usia Anak & 48,3 \\
Masa kanak-kanak (5-11 th) & 31,7 \\
Masa remaja (12-17 th) & 20 \\
Masa dewasa (18-40 th) & \\
Kemampuan baca tulis & 90 \\
Mampu membaca dan menulis & 10 \\
Tidak mampu membaca dan menulis & \\
Hubungan Anak & 15 \\
Ayah Kandung & 85 \\
Ibu Kandung & \\
Jumlah Anak & 15 \\
1 & 36,7 \\
2 & 35 \\
3 & 13,3 \\
$\geq 4$ & \\
Suku & 95 \\
Jawa & 56,7 \\
Kelompok suku yang lain & 6,7 \\
Agama & 6,7 \\
Islam & 31,7 \\
Katolik & 3,3 \\
Pendidikan Terakhir & 13,3 \\
SD & \\
SMP & \\
SMA & \\
Diploma & \\
Sarjana & \\
\hline
\end{tabular}

Tabel 2 menunjukkan tidak ada responden yang memiliki kategori sangat rendah untuk kualitas relasi maupun resiliensi. Sebagian besar responden memiliki kategori tinggi baik untuk variabel kualitas relasi maupun resiliensi.
Kualitas hubungan orang tua-anak yang tinggi dimaknai sebagai interaksi timbal balik yang baik antara anak dan orang tua yang akan menimbulkan keakraban dalam keluarga. Anak akan terbuka kepada orangtua, sehingga komunikasi dapat berlangsung secara dua arah dan segala permasalahan dapat dipecahkan bersama karena terdapat kedekatan dan kepercayaan antara orang tua dan anak. Berdasarkan penuturan dari ketiga responden, semua memiliki kontrol yang sama yaitu demokratis.

Dukungan orang tua, yang mencerminkan ketanggapan orang tua atas kebutuhan anak merupakan hal yang sangat penting bagi anak (4). Dukungan penuh kepada anak diberikan oleh semua responden. Ketiga responden berusaha untuk dapat menjalin komunikasi dengan anak meskipun anak mengalami hambatan dalam bahasa.

Resiliensi yang tinggi dalam penelitian ini dimaknai sebagai kemampuan yang tinggi orang tua untuk menilai, mengatasi dan meningkatkan diri ataupun mengubah diri dari keterpurukan atau kesengsaraan dalam hidup, karena setiap orang pasti mengalami kesulitan ataupun sebuah masalah seperti yang terjadi pada orang tua anak tuna grahita karena tidak ada satu orang pun di dunia ini yang tidak mengalami kesulitan dalam hidup.

Tabel 2. Tanggapan responden terhadap variabel

\begin{tabular}{llcccc}
\hline & & \multicolumn{4}{c}{ Resiliensi } \\
\cline { 3 - 6 } & & Rendah Tinggi Sangat tinggi & Total \\
\hline \multirow{2}{*}{ Kualitas } & Rendah & 0 & 5 & 3 & 8 \\
Relasi & Tinggi & 1 & 20 & 26 & 47 \\
& $\begin{array}{l}\text { Sangat } \\
\text { tinggi }\end{array}$ & 0 & 3 & 2 & 5 \\
\hline Total & & 1 & 28 & 31 & 60 \\
\hline
\end{tabular}

Tabel 3 menunjukkan nilai rata-rata keseluruhan dari item pernyataan variabel resiliensi berada pada kategori tinggi berdasarkan mean masing-masing sub variabel. Berdasarkan hasil tersebut dapat disimpulkan bahwa kemampuan berada pada kategori tinggi karena nilai rata-rata keseluruhan hampir 100\%. Terlihat bahwa orang tua yang memiliki derajat resiliensi yang tinggi memiliki ketujuh aspek resiliensi yang tinggi.

Tabel 3. Gambaran derajat resiliensi dan aspek-aspeknya

\begin{tabular}{|c|c|c|c|c|c|c|c|}
\hline $\begin{array}{c}\text { Derajat } \\
\text { Resiliensi }\end{array}$ & $\begin{array}{c}\text { Regulasi } \\
\text { Emosi }\end{array}$ & $\begin{array}{l}\text { Kontrol } \\
\text { Impuls }\end{array}$ & Optimisme & Analisis Kausal & Empati & Efikasi Diri & Pencapaian \\
\hline Tinggi & $100 \%$ & $100 \%$ & $98,33 \%$ & $88,33 \%$ & $100 \%$ & $100 \%$ & $98,33 \%$ \\
\hline Rendah & $0 \%$ & $0 \%$ & $1,67 \%$ & $11,67 \%$ & $0 \%$ & $0 \%$ & $1,67 \%$ \\
\hline Total & $100 \%$ & $100 \%$ & $100 \%$ & $100 \%$ & $100 \%$ & $100 \%$ & $100 \%$ \\
\hline
\end{tabular}




\section{BAHASAN}

Hasil penelitian menunjukkan bahwa mayoritas jenis kelamin responden adalah laki-laki sebanyak 42 responden (70\%), sedangkan responden perempuan sebanyak 18 orang (30\%). Menurut Delgado, gender memberikan kontribusi bagi resiliensi individu. Risiko kerentanan terhadap tekanan emosional, perlindungan terhadap situasi yang mengandung risiko, dan respon terhadap kesulitan yang dihadapi dipengaruhi oleh gender (3).

Sebagian besar responden adalah usia kanak-kanak karena disabilitas intelektual adalah keadaan dengan intelegensia yang kurang (subnormal) yang terjadi atau muncul sejak masa perkembangan (sejak lahir atau sejak masa anak). American Phychological Association (APA) yang dipublikasikan melalui Manual of Diagnosis and Professional Practice in Mental Retardation tahun 1996, mengemukakan tentang batasan disabilitas intelektual. Batasan dari APA ini dapat dimaknai, bahwa anak disabilitas intelektual adalah anak yang secara signifikan memiliki keterbatasan fungsi intelektual, keterbatasan fungsi adaptif (5). Keadaan ini terjadi sebelum usia 22 tahun. Batasan dari APA dan AAMR ini letak perbedaannya pada usia munculnya disabilitas intelektual, yaitu sebelum usia 18 tahun (batasan dari AAMR) dan sebelum 22 tahun (APA). Batasan ini apabila disatukan, maka dapat dikatakan, bahwa keterbatasan fungsi intelektual dan fungsi adaptif nampak sebelum usia 18-22 tahun (6).

Sebagian besar responden mampu membaca menulis. Pendidikan responden mayoritas adalah SMA Menurut Holaday (3), keterampilan kognitif berpengaruh penting pada resiliensi individu. Intelegensi minimal rata-rata dibutuhkan bagi pertumbuhan resiliensi pada diri individu karena resiliensi sangat terkait erat dengan kemampuan untuk memahami dan menyampaikan sesuatu lewat bahasa yang tepat, kemampuan membaca, dan komunikasi non verbal.

Sebagian besar responden, meliputi 51 orang (85\%) responden merupakan ibu kandung sedangkan 9 orang (15\%) responden merupakan ayah kandung. Bila dilakukan pembandingan antara ibu dan ayah, diketahui bahwa ibu tahu lebih banyak tentang aktivitas yang dilakukan anak dan mendapatkan informasi melalui supervisi yang aktif atau kerelaan anak untuk terbuka daripada ayah. Adapun ayah lebih banyak mendapatkan informasi dari ibu (4).

Jumlah anak yang dimiliki responden terbanyak 22 responden (36,7\%) memiliki 2 anak, 21 responden (35\%) memiliki 3 anak, 9 responden (15\%) memiliki 1 anak dan sisanya 8 responden (13,3\%) memiliki lebih dari 3 anak. Sebagian besar responden adalah suku jawa dengan jumlah 57 responden (95\%) dan 3 responden suku adalah suku yang lain. Beuf (3) mengungkapkan bahwa resiliensi dipengaruhi secara kuat oleh kebudayaan, baik sikap-sikap yang diyakini dalam suatu budaya, nilai-nilai, dan standar kebaikan dalam suatu masyarakat. Kajian antropologi mengungkapkan pengasuhan anak dalam keluarga Jawa lebih menekankan pada kontrol emosi diri dan harmoni dalam hubungan sosial. Sebagai implikasinya masyarakat Jawa tidak mendorong kemunculan perilaku agresi terhadap teman sebaya apalagi terhadap orang tua. Anak-anak didorong untuk menyelesaikan masalah dengan bermusyawarah daripada menggunakan agresi fisik dan verbal. Anak-anak yang menggunakan pembalasan secara fisik dan verbal akan mendapatkan teguran, sedangkan anak yang mampu menenangkan dirinya serta pihak yang menyerangnya akan mendapatkan ganjaran (4).

Agama responden sebagian besar adalah Islam. Menurut Prasa, keyakinan dan nilai tertentu yang dianut akan menjadi sangat penting karena akan menuntun individu menilai sebuah peristiwa sehingga dapat dinilai secara positif. Witmer mencatat, penggunaan ajaran agama dan kepercayaaan spiritual adalah bangunan yang sering dilupakan dalam strategi koping (7).

Relasi orang tua-anak yang diwarnai kehangatan memungkinkan anak memiliki kemampuan untuk dapat melibatkan diri dengan lingkungan sosial. Sebaliknya, relasi orang tua-anak yang dingin akan menyebabkan anak senantiasa menarik diri dari lingkungan sosial. Sikap dan perlakuan orang tua yang toleran, permisif, turut terlibat dan penuh kehangatan merupakan manifestasi dari penerimaan orang tua terhadap anak. Sikap dan perlakuan orang tua yang tidak toleran, keras, membiarkan dan dingin merupakan bentuk penolakan terhadap anak (7). Sikap demokratis memang telah dibiasakan oleh orang tua yang menjadi responden dalam penelitian ini. Ketiga responden menghendaki lingkungan keluarga yang toleran, penerimaan terhadap anak yang diwujudkan dalam hubungan yang penuh kehangatan.

Kesimpulan dari hasil wawancara awal dan pengamatan yang dilakukan terhadap 3 orang tua anak disabilitas intelektual tersebut adalah orang tua anak disabilitas intelektual cukup mampu meyakini kemampuan sendiri, terutama dalam mengasuh dan merawat anak, merasa optimis dalam menghadapi keadaan diri dan anak, mampu menghadapi tantangan atau cobaan terkait dengan keadaan yang dialami. 
Penelitian ini tidak menemukan korelasi antara kualitas relasi orang tua-anak dengan resiliensi orang tua anak disabilitas intelektual. Kualitas relasi dan resiliensi dalam penelitian ini sebagian besar berkategori tinggi akan tetapi secara statistik terbukti tidak ada korelasi. Resiliensi dipengaruhi oleh beberapa variabel seperti dukungan (8). Penelitian lain menunjukkan bahwa individu memiliki tiga sumber resiliensi yaitu menerima dukungan dari orang tua, guru beserta teman-temannya (I Have), memiliki kepercayaan diri yang baik seperti anak normal lain (I $A m$ ) dan mampu menjalin hubungan sosial dan interpersonal dengan baik (I Can) (8).

Hasil penelitian ini bertentangan dengan hasil penelitian Miller-Lewis et al. yang membuktikan bahwa strategi intervensi dan pencegahan dini yang berfokus pada pengembangan anak-dewasa termasuk kualitas hubungan, konsep diri, dan pengendalian diri pada anak-anak dapat membantu membangun kesehatan mental anak-anak dan ketahanan mereka dalam masalah keluarga (10). Penelitian Miller-Lewis et al. menggunakan sampel komunitas 474 anak-anak prasekolah di Australia (usia rata-rata 4,59 tahun, 49\% laki-laki) dan menggunakan kuesioner untuk menilai kualitas hubungan anak-anak dengan kedua orang tua dan guru, konsep diri dan pengendalian diri, kesehatan mental dan ketahanan keluarga (9). Penelitian yang meneliti tentang variabel kualitas relasi pada anak tuna grahita diharapkan memahami dan mengeksplorasi setiap aspek dalam variabel kualitas relasi lebih mendalam dengan memperhatikan validitas konten instrumen.

\section{SIMPULAN}

Tidak terdapat hubungan signifikan antara kualitas relasi orang tua-anak dengan resiliensi orang tua anak tuna grahita. Hal ini berarti, peningkatan resiliensi tidak dipengaruhi oleh kualitas relasi. Penulis menyarankan penelitian selanjutnya perlu mempertimbangkan variabel lain yang juga menyertai seperti dukungan sosial.

Bagi orang tua, walaupun pada hasil penelitian ini kualitas relasi tidak berhubungan dengan resiliensi, namun berdasarkan hasil penelitian responden memiliki kategori tinggi baik pada variabel kualitas relasi maupun resiliensi. Orang tua yang memiliki anak tuna grahita tetap meningkatkan ketahanan dalam mengasuh anak, sehingga mampu mengubah kondisi yang tidak menguntungkan menjadi kesuksesan.

\section{Abstrak}

Tujuan: Penelitian ini untuk mengetahui hubungan kualitas relasi orang tua-anak dengan resiliensi orang tua anak disabilitas intelektual. Metode: Penelitian cross sectional ini dilakukan pada bulan Juni - Juli 2015 di SLB N 1 Bantul kota Yogyakarta sedangkan uji coba instrumen dilakukan pada 20 orang tua yang memiliki anak disabilitas intelektual di SLB Darma Bhakti Piyungan, Yogyakarta. Populasi dalam penelitian ini adalah semua orang tua dengan anak disabilitas intelektual di SLB N 1 Bantul dari tingkat TKLB sampai SMALB. Sampel sebanyak 60 responden. Hasil: Penelitian ini tidak menemukan hubungan bermakna antara kualitas relasi orang tua-anak dengan resiliensi orang tua dengan anak disabilitas intelektual. Simpulan: Variabel resiliensi tidak berhubungan langsung dengan variabel kualitas relasi melainkan dengan variabel penyerta lain seperti dukungan sosial.

Kata Kunci: kualitas relasi; resiliensi; disabilitas

\section{PUSTAKA}

1. Maslim R. Buku Saku Diagnosis Gangguan Jiwa (PPDGJ III). Jakarta: FK Jiwa Unika Atmajaya; 2013.

2. Ayu. Hubungan Religiusitas dengan Resiliensi pada Ibu yang Memiliki Anak Retardasi Mental. Universitas Kristen Satya Wacana; 2012.

3. Lestari S. Psikologi Keluarga Penanaman Nilai dan Penanganan Konflik dalam Keluarga. Jakarta: Kharisma Putra Utama; 2012.

4. Nuckols CC. The Diagnostic and Statistical Manual of Mental Disorders, Fifth Edition (DSM-5) [Internet]. 2000. Available from: http://dhss.delaware.gov/dsamh/files/si2013_dsm5f oraddictionsmhandcriminaljustice.pdf

5. Wati. Outbond Management Training untuk meningkatkan Kemampuan Penyesuaian Diri Anak Tunagrahita. Universitas Negeri Semarang; 2012.

6. Armita, Yulia. Faktor-faktor yang mempengaruhi Resiliensi Anak Berkebutuhan Khusus Tunadaksa Berprestasi di SLB Wacana Asih Kota Padang. Universitas Andalas; 2014.

7. Prasa. Stres dan Koping Orangtua dengan Anak Retardasi Mental. Universitas Ahmad Dahlan; 2012.

8. Ariani. Korelasi Pola Hubungan Orangtua-Anak dan Keberfungsian Keluarga dengan Perkembangan Anak Usia Prasekolah. Universitas Sebelas Maret; 2009.

9. Miller-Lewis LR, Searle AK, Sawyer MG, Baghurst PA, Hedley D. Resource factors for mental health resilience in early childhood: An analysis with multiple methodologies. Child Adolesc Psychiatry Ment Health. BioMed Central; 2013 Feb 22;7(1):6. 
Berita Kedokteran Masyarakat, Volume 33 No. 4 Tahun 2017 